\title{
Determinants of voluntary CSR disclosure: empirical evidence from Germany
}

\author{
Ramin Gamerschlag • Klaus Möller • \\ Frank Verbeeten
}

Received: 5 July 2010/Accepted: 5 October 2010/Published online: 5 November 2010

(C) The Author(s) 2010. This article is published with open access at Springerlink.com

\begin{abstract}
Currently, companies spend a great deal of effort on Corporate Social Responsibility (CSR) disclosures. CSR disclosure relates to the provision of information on companies' environmental and social performance. From an economic perspective, companies might disclose this information to avoid or decrease potential political costs. We construct a CSR disclosure index based on the Global Reporting Initiative (GRI) guidelines. Using content analysis, we analyze 130 listed German companies' CSR disclosures (470 firm-year observations) to investigate the determinants of these voluntary disclosure activities. Our results show that, consistent with the political cost theory, German companies' disclosures of all CSR issues are affected by their visibility, shareholder structure, and relationship with their US stakeholders. In addition, higher profitability is associated with more environmental disclosures. Finally, size and industry membership affect the amount of CSR disclosure.
\end{abstract}

Keywords Corporate Social Responsibility - Content analysis · Global reporting initiative $\cdot$ Voluntary disclosure

Mathematics Subject Classification (2000) 62J05

\footnotetext{
R. Gamerschlag $(\bowtie) \cdot$ K. Möller

Faculty of Economic Sciences,

Georg-August-Universität Göttingen,

Platz der Göttinger Sieben 3, 37073 Göttingen, Germany

e-mail: Ramin.Gamerschlag@wiwi.uni-goettingen.de

F. Verbeeten

Department of Accounting and Control,

Rotterdam School of Management,

Erasmus Universiteit Rotterdam, Burgemeester Oudlaan 50,

3062 PA Rotterdam, The Netherlands
} 


\section{Introduction}

Corporate Social Responsibility (CSR) refers to a company's voluntary contribution to sustainable development which goes beyond legal requirements. During the last years, we have seen an increase in CSR (media) campaigns and in corresponding disclosure activities. Today, large companies specifically spend a great deal of effort and money on disclosing information on their social and environmental performance.

From an economic perspective, companies should only undertake actions that reduce costs or enhance benefits; that is, only disclosures that reduce costs or increase revenues are desirable. We argue that due to firm-specific characteristics, companies have to deal with either more or less powerful stakeholders and thus face different levels of political and societal costs. By voluntarily disclosing information on their social and environmental performance, companies try to reduce these costs. Consequently, we argue that CSR disclosure is determined by a number of such firm-specific determinants acting as proxies for political and societal costs. In this paper, we try to identify the determinants that induce companies to disclose CSR information. ${ }^{1}$

To test our hypotheses, we construct a CSR disclosure index based on the Global Reporting Initiative (GRI) guidelines. The GRI provides a framework of the societal and environmental issues that should be disclosed in corporate reports. We use a hand-collected set of specific CSR data (extracted from the reports by means of content analysis), as well as 130 listed German companies' underlying firm-specific characteristics (470 firm-year observations). Our results are mostly consistent with our hypotheses: a company's visibility, its shareholder structure, and its relationship with US stakeholders affect CSR disclosure. In addition, profitability affects environmental disclosure, a specific category within the CSR disclosures.

Our study contributes to a greater understanding of the variation in companies' CSR disclosures. First, we provide evidence of CSR disclosures in Germany, which is an interesting setting as companies are not required to disclose CSR information. Therefore, the provision of CSR information is voluntary and not bound by regulation. Other European countries (e.g., the UK, France, and the Netherlands) have more specific guidelines or requirement for the provision of CSR information (Kolk et al. 2001). These differences in regulatory environments may have affected the results of previous studies focusing on a European level (e.g., Kolk 2005; Kolk et al. 2001; Maignan and Ralston 2002; Meek et al. 1995).

Furthermore, while former studies have often focused on either annual reports (Cormier and Gordon 2001) or on specific CSR reports (Tate et al. 2010), we focus on the various reports that companies could use to disclose CSR information. This includes the annual report (which is mandatory), but also voluntary CSR reports, as well as other specific reports (e.g., environmental, social, and human capital reports). Additionally, prior studies have often not considered all aspects of CSR, but have focused on either environmental or social disclosures (Bewley and $\mathrm{Li}$

\footnotetext{
${ }^{1}$ Note that we only focus on disclosures, not on a company's overall CSR performance. Companies' social and/or environmental performances may be bad, but they make abundant CSR disclosures.
} 
2000; Deegan and Gordon 1996; Déjean and Martinez 2009; Lynch 2009). Those studies that take both perspectives into consideration (e.g., Guthrie and Farneti 2008) have mostly applied one-dimensional measures (e.g., the number of pages with CSR information in relation to the total number of report pages). Such measures don't account for the different CSR facets. In our study, we consider both CSR disclosure dimensions by dividing the provided information into an environmental and a social perspective, as well as an overall measure for CSR disclosure. Finally, we extend the set of CSR disclosure determinants by including factors like the shareholder structure, the company's visibility, its industry membership, and its relationship with its US stakeholders.

The article is structured as follows: in the next section, we will review the relevant theory and derive the hypotheses to be tested. Section 3 contains the study design and the methodology. Section 4 presents our results together with a discussion and interpretation of these. The study concludes with a summary, a description of its limitations, and an outlook on further research.

\section{Theory and hypotheses development}

\subsection{Theoretical perspectives on CSR disclosure}

Corporate Social Responsibility (CSR) can be defined as a company's voluntary contribution to sustainable development which goes beyond legal requirements (Bowen 1953; Carroll 1999, 2006; Crane and Matten 2007; De Bakker et al. 2005). Under the current ${ }^{2}$ "profit-maximizing CSR perspective," firms have to consider the social and environmental costs and benefits to maximize their value (Bowen 1953; Callens and Tyteca 1999; Drucker 1984; Gladwin et al. 1995; McWilliams and Siegel 2001). That is, companies are assumed to be socially responsible because they anticipate benefiting from these actions. Examples of such benefits might include the ability to charge a premium price for its output or the use of CSR to recruit and retain high quality workers. These benefits are presumed to offset the higher costs associated with CSR, since resources must be allocated to allow the firm to achieve a higher CSR status (Siegel and Vitaliano 2007).

The growing CSR awareness is also reflected in the increasing number of CSR and sustainability reports, as well as in the provision of CSR-related information (e.g., through advertising; Gray et al. 2001; Kolk 2005). CSR disclosure can be defined as the information that a company discloses about its environmental impact

\footnotetext{
${ }^{2}$ Historically, economists have developed two contrary approaches to CSR. On the one hand, there is neo-classical economics' traditional perspective: a company's main objective is to maximize the shareholder value. Hence, companies should only undertake actions which either increase profits or decrease costs, while adhering to all legal principles and protecting its integrity (Friedman 1962, 2007; Husted and Salzar 2006; Rappaport 1998). The neo-classical economics' traditional perspective has mostly disparaged CSR (Aupperle et al. 1985; Friedman 2007). On the other hand, the stakeholder approach constitutes the theoretical basis of most arguments supporting CSR. It argues that companies should try to fulfill all stakeholders' demands, which—at least in the long term-results in higher economic profits (Donaldson and Preston 1995; Freeman 1984; Frooman 1999).
} 
and its relationship with its stakeholders by means of relevant communication channels (Campbell 2004; Gray et al. 2001).

Many different theoretical attempts have been made to explain why companies voluntarily disclose CSR information (Dowling and Pfeffer 1975; Gray et al. 1995a; Guthrie and Parker 1989; Patten 1991). We rely on political cost theory to develop our hypotheses. The political cost theory suggests that managers are concerned with political considerations, including preventing explicit or implicit taxes, or other regulatory actions (Healy and Palepu 2001; Jensen and Meckling 1978; Watts and Zimmermann 1978). In addition to politicians, non-governmental interest groups and other stakeholders increasingly try to influence companies' actions to favor their specific interests. They thus have the power to affect wealth transfers between the company and other stakeholders. Our assumption is that by disclosing information on their social and environmental performance, firms want to minimize the (potential) costs arising from the interaction between the firm and its natural and societal environment—referred to as political or societal costs (Fields et al. 2001).

Companies can employ a number of methods to reduce the likelihood of adverse political or societal actions and the resulting costs (Watts and Zimmermann 1978). One of them is to disclose CSR information, as this allows the firm to generate moral capital that, for example, can temper punitive sanctions in the case of a negative event (Blacconiere and Patten 1994; Godfrey 2005). Empirical evidence seems to confirm this notion. For instance, Lyon and Maxwell $(2006,2007)$ find that firms with poor reputations disclose fully, while firms with excellent reputations disclose nothing, as they gain little by disclosing successes since they are expected to succeed.

We argue that-due to their specific characteristics-companies face different intensities of external pressures as a function of their stakeholders' particular levels of power, legitimacy, and urgency (Agle et al. 1999; Mitchell et al. 1997). Consequently, companies deal with different political costs and benefits. Therefore, we argue that the answer to the question why firms disclose CSR information is quite simple: because it is in their (economic) interest. A company is hypothesized to engage in CSR if it anticipates that the benefits will be greater than the costs (Siegel and Vitaliano 2007), and any decision to voluntary disclose information on CSR issues results from these trade-offs between the expected costs and benefits (Dye 1985; Verrecchia 1983).

Different firm-specific characteristics act as a proxy for the degree of stakeholder pressure that companies face. We argue that these firm characteristics determine whether CSR disclosure occurs or not. ${ }^{3}$ Other attempts to explain voluntary CSR disclosures have also suggested that firm characteristics are important determinants of disclosure activities (Cormier and Gordon 2001; Meek et al. 1995). Empirical studies have used a wide range of measures that, for example, include industry membership, the number of shareholders, and press coverage (Milne 2002). We utilize a broader range of factors which, in previous (theoretical) literature, has been identified as

\footnotetext{
3 Firm size, for instance, has often been mentioned as a central indicator of the amount of political or societal costs but was found to act as a proxy for more than just political costs (Ball and Foster 1982; Milne 2002).
} 
potential determinants of voluntary disclosure decisions: company visibility, profitability, the shareholder structure, and the company's relationship with its US stakeholders. In addition, we control for the effects of industry membership and firm size. On the basis of these determinants, we develop four hypotheses, which will form the foundation of our further analysis in the following sections.

\subsection{Hypotheses development}

\subsubsection{Company visibility}

Some companies are more visible to the public than others. Their degree of visibility depends, amongst others, on the quantity of their (business) press coverage. Companies constantly in the media spotlight are especially susceptible to political actions, since they attract more attention from stakeholders than less visible companies (Deegan and Carroll 1993; Powell 1991). These stakeholders (including pressure groups) are interested in these companies' activities and try to influence them. Consequently, visible companies are more affected by social constraints and pressures than companies which are less visible to the public (Belkaoui and Karpik 1989; Brammer and Millington 2006; Holthausen and Leftwich 1983). That is, they are potentially subject to higher political or societal costs as a result of their exposed position in the public. Thus, highly visible companies are assumed to disclose more CSR-related information to reduce potential political costs than less visible companies (Belkaoui and Karpik 1989). Based on previous reasoning, we assert that

H1 CSR disclosure is positively associated with company visibility.

\subsubsection{Profitability}

Profitable firms could face higher social constraints and public exposure than less profitable firms (Holthausen and Leftwich 1983; Watts and Zimmermann 1978, 1990). They are more affected by potential political costs, especially if they appear "overly" profitable (Fields et al. 2001; Han and Wang 1998). As a result, profitable companies may have to explain that they operate within the (explicit or implicit) norms of society, as they will find it costly to be associated with actions that breach society's expectations (Islam and Deegan 2010). Therefore, profitable companies could be more interested in explaining-via CSR disclosure-how they "produce" their profitability than less profitable companies (Bewley and Li 2000). In addition, profits provide managers with resources from which the costs of disclosures are funded (Brammer and Pavelin 2006). ${ }^{4}$ On the basis of the previous arguments, we propose that

H2 CSR disclosure is positively associated with profitability.

\footnotetext{
4 Alternatively, profitability could also indicate that the company might not care about social and environmental aspects. In other words, the company's profitability is achieved through the exploitation of its workforce or the environment. This could lead to profitable companies disclosing less information on their "CSR performance" than less profitable companies. However, it is unlikely that this argument is viable in the long run.
} 


\subsubsection{Shareholder structure}

The potential for conflicts between owners (principals) and managers (agents) is greater in companies where shares are widely distributed rather than in more closely held companies. The reason is twofold: when ownership is dispersed, shareholders have little direct authority over managers and must therefore monitor their activities (Brammer and Pavelin 2006); in addition, communication between relevant parties is hindered (Fama and Jensen 1983). Consequently, voluntary disclosures are likely to be greater in widely held firms, allowing the principals to effectively monitor that their economic interests are optimized, while agents can signal that they act in the owners' best interests (Chau and Gray 2002; Fama and Jensen 1983). Moreover, companies with few big shareholders (e.g., family-owned firms) have little motivation to disclose information, especially in excess of mandatory requirements, because the demand for public disclosure is relatively weak (Chau and Gray 2002). Furthermore, large shareholders normally obtain information in other ways than through company reports. They often have direct access to the management board, which results in lower information asymmetry between them and the managers (Chen et al. 2008). On the other hand, disclosure activities are usually directed at a large, dispersed group of relatively small shareholders. Finally, public accountability may become more important, because there is a greater trend towards widely dispersed companies held by the public at large (Ghazali 2007). A higher level of public accountability may necessitate additional involvement in social or community activities and, hence, disclosure of these activities. This suggests that companies with a big group of small shareholders are likely to provide more CSR-related information in their reports to reduce the potential political costs. Based on the previous review, we posit that:

H3 CSR disclosure is positively associated with more dispersed share ownership structures.

\subsubsection{Relationship with US stakeholders}

Societies have developed different political, financial, and cultural systems reflecting their institutions, ethics, and social relations (Whitley 1999). That is, stakeholder identities and interests vary cross-nationally. Accordingly, political costs are likely to vary across nations, given that they reflect cultural and social norms (Meek et al. 1995). Matten and Moon (2008) argue that in liberal market economies, for example in the US, disclosure of CSR activities is more common than in Scandinavian and Continental European countries. For instance, in the US there is greater scope for corporate discretion, since government is less powerful than in most European countries and European governments have generally been more engaged in economic and social activities (Lijphart 1984, Matten and Moon 2008). Consequently, the US system leaves more incentives and opportunities for companies to assume comparatively explicit responsibility.

Against this background, Matten and Moon (2008) mention explicit CSR in the US and implicit CSR in Europe. Explicit CSR refers to corporate policies that 
convey responsibility for certain societal interests; this responsibility normally consists of companies' voluntary programs and strategies that combine social and business value, and address issues perceived as part of the company's social responsibility. Implicit CSR, on the other hand, refers to companies' role within the wider formal and informal institutions to address society's interests and concerns. Implicit CSR normally consists of values, norms, and rules that result in companies being (mandatorily and customarily) required to address stakeholder issues and that define corporate actors' appropriate obligations in collective rather than individual terms. Matten and Moon (2008) argue that US corporations tend to provide more CSR information, as this provides them with the opportunity to distinguish themselves from their competitors. Such an explicit CSR disclosure is the result of a corporation's deliberate, voluntary, and often strategic decision. On the other hand, Continental European firms operate in an environment in which CSR is not seen as a voluntary and deliberate corporate decision but as a reaction to, or a reflection of, a corporation's institutional environment (Matten and Moon 2008).

Differences in the CSR environment are likely to affect voluntary CSR disclosures, since, at the very least, cultural aspects influence the issues which companies select as worthy of disclosure (Kolk et al. 2001; Langlois and Schlegelmilch 1990; Matten and Moon 2008). Specifically, we argue that organizational practices (in our case, voluntary CSR disclosures) change when companies start operating and financing (part of) their organization in a different institutional environment (Matten and Moon 2008). Empirical evidence supports this notion; for example, Bancel and Mittoo (2001) find that European companies disclose more information when they are cross-listed on a US stock exchange, suggesting that disclosure levels change when companies move into different institutional environments. Since CSR disclosures tend to be more pervasive in the US, ${ }^{5}$ we hypothesize that companies provide more CSR information when they deal with US stakeholders:

H4 CSR disclosure is positively associated with a company's relationship with its US stakeholders.

\subsection{Control variables}

Stakeholder pressures, as well as the resulting political costs are influenced by the industry to which a company belongs (Brammer and Millington 2006; Verrecchia 1983). For instance, companies with a high environmental impact receive more attention from environmental lobby groups; these groups try to influence politicians and the general public to impose costs on those firms with poor environmental performance. Consequently, these firms have more incentives to disclose CSR information in general and environmental information in particular to reduce the

\footnotetext{
${ }^{5}$ Note that there are also considerable differences with regard to the required disclosures across European countries. For example, in the Netherlands, more than 200 firms with a significant environmental impact are required to publish environmental reports. This legal obligation strongly influences disclosure levels, since the relevant companies disclose much more CSR information than their counterparts (Kolk et al. 2001). However, firms in our sample are not required to disclose information; therefore, we expect that those with a US listing will tend to provide more CSR information to comply with customary US disclosure patterns.
} 
impending costs (Deegan and Gordon 1996). For instance, chemical companies are likely to be more sensitive about disclosures to the public than companies in most other industries (Meek et al. 1995). Previous literature confirms that industry membership is associated with corporate disclosures (Cowen et al. 1987; Deegan and Gordon 1996; Holder-Webb et al. 2008; Meek et al. 1995; Patten 1991). Consequently, we use industry membership as a control variable.

Firm size is our second control variable. Large firms tend to be more visible to the public and tend to be subject to greater political and regulatory pressures from external interest groups (Meek et al. 1995; Roberts 1992; Watts and Zimmermann 1978, 1986, 1990). To reduce these (potential) political costs, large firms disclose more information to demonstrate that their actions are legitimate and consistent with good corporate citizenship (Brammer and Pavelin 2006). Furthermore, larger organizations are more likely to use formal channels of communication (e.g., annual reports or other corporate documentation) to disseminate CSR information (Brammer and Pavelin 2006). Previous empirical studies confirm the association between firm size and the level of CSR disclosures (e.g., Cowen et al. 1987; Meek et al. 1995; Patten 1991; Cho et al. 2009; Cormier and Gordon 2001; Deegan and Gordon 1996; Dowling and Pfeffer 1975; Gray et al. 1995a; Holder-Webb et al. 2008; Roberts 1992). Finally, we use year dummies to control for time effects.

\section{Design of the study and methodology}

\subsection{Sample construction}

Our analysis focuses on Germany for two reasons: comparability (i.e., exclusion of institutional differences between countries) and the voluntary disclosure environment. As pointed out earlier, CSR and, thus, CSR disclosure differ between countries (Matten and Moon 2008; Van der Laan-Smith et al. 2005). To generate a homogenous dataset, we decided to concentrate on corporations with an identical political and societal background-thus on companies from the same country. We chose Germany as it has no official regulation on how to report on social and environmental aspects. Therefore, CSR disclosure is completely voluntary.

We focus on the German DAX, MDAX, and SDAX. These three indexes include the 130 biggest listed German companies. Our sample focuses on the index composition as at the end of 2008 . We consider four reporting periods ${ }^{6}$ between 2005 and 2008; this results in 520 firm-year observations. We only consider reports provided in English (all companies in the sample provide their reports in English as well as in German). Since some companies' reports are not available for all the years (for instance, if a company entered one of the indices after 2006), our sample was reduced by 35 observations. Furthermore, we lost 15 observations due to other

\footnotetext{
${ }^{6}$ The SDAX's composition changes very frequently, as companies continuously enter or leave the index. Considering more than four reporting periods in our analysis would therefore have disproportionately shortened the number of observations in the sample.
} 
missing information, for example, on the shareholder structure. Our final dataset consists of a total of 470 firm-year observations.

\subsection{Content analysis}

In this analysis, we are interested in the CSR information (message) transmitted by corporate reports (communication channel) and provided by the sample companies (source) to their stakeholders (receiver; see Shannon and Weaver 1998). Similar to previous studies, we use content analysis to quantify the amount of CSR information in the reports. We apply a so-called "third party approach" in which content analysis is carried out by someone who is neither a provider (source) nor a receiver of the report.

Content analysis is a method of codifying written text into various groups or categories on the basis of selected criteria. It assumes that frequency is an indication of the subject matter's importance (Abdolmohammadi 2005; Guthrie et al. 2004; Krippendorff 2004). Its objective lies in generating a numerically based summary of a chosen message set (Krippendorff 2004; Neuendorf 2002). Previous literature suggests that content analysis provides valid results for corporate social and environmental reporting research, thus allowing the researcher to evaluate the extent of various items' disclosure (Deegan and Gordon 1996; Déjean and Martinez 2009; Gray et al. 1995b; Guthrie et al. 2004; Guthrie and Farneti 2008; Guthrie and Parker 1989).

\subsubsection{Unit of analysis}

A key issue in content analysis is the unit of analysis. A unit is an identifiable component of a communication through which variables are measured (Holsti 1969; Krippendorff 2004; Neuendorf 2002). Depending on the unit of analysis, there are several ways of applying content analysis, for instance, by counting words, sentences or sections, or by reading the whole text (Neuendorf 2002). Another possibility is to use advanced software packages to extract information from reports (e.g., Chen and Bouvain 2009, Tate et al. 2010). We decided to use words as the unit of analysis because the coder is not required to provide subjective judgment. Furthermore, searching for specific terms in the text is regarded as the most reliable form of content analysis: it always yields the same results in repeated trials, as it can be easily replicated (Abdolmohammadi 2005). We used the PDF reader's word count function after manually checking its validity.

\subsubsection{Identification of keywords}

In line with previous research (Guthrie et al. 2008; Guthrie and Farneti 2008; Holder-Webb et al. 2008), we derived the keywords for our content analysis from the framework of the Global Reporting Initiative (GRI). Although it is not free from criticism, the GRI is regarded as the most relevant institution in the context of CSR disclosure (Moneva et al. 2006) and is often referred to as the global standard. Owing to the voluntary nature of the guidelines, organizations have the flexibility to 
decide what information to disclose. The GRI guidelines cover all aspects of CSR, as they consider an economic, environmental, and a social perspective. Since companies are obliged to disclose financial and, thus, economic information, we only incorporate the environmental and social perspectives in our coding framework.

The GRI guidelines provide indicators of all three CSR perspectives. These indicators can be split into core indicators and additional ones. Core indicators are of interest to most stakeholders, and are therefore relevant for most companies, while additional indicators are only of interest to some stakeholders and companies (GRI 2010). We derived the keywords for our analysis from the core indicators by defining one or more keywords for every indicator, thus considering the singular and plural forms ("equal opportunity"/“equal opportunities"), as well as British and American English ("labour"/"labor"). By having derived the keywords from a well-grounded framework like the GRI guidelines, we improve the results' validity, as the guidelines can be assumed to reflect CSR's "real meaning." As shown in Table 1, we finally obtain a total number of 32 keywords.

\subsubsection{Communication channel}

We focus on reports provided proactively on the companies' website. In general, there are different ways of disclosing information on CSR. First, companies may integrate CSR-related aspects into their annual/financial reports by enhancing these reports. Second, companies may provide special/separate CSR or sustainability reports (in addition to their annual reports). Companies may also provide information on CSR-related issues through various corporate reports, for example, through separate financial, environmental, social, and human capital reports. Finally, companies may use other media, for example, press releases, to disclose CSR-related information. In our analysis, we concentrate on the first three possibilities, thus taking the most important communication channels for CSR disclosure into account.

\subsection{Dependent variables: CSR disclosure}

Our first variable of interest is whether companies provide a separate CSR report (denoted CSRR), as it can be assumed that companies disclose more CSR information if they provide special CSR reports. CSRR is a dummy variable that indicates whether or not a separate CSR report is provided in the corresponding year (' 1 ' indicates a separate report, ' 0 ' otherwise). We derived the other three variables from the reports provided by the sample companies. We compiled three variables extracted from the provided reports ${ }^{7}$ by using content analysis based on the defined keywords:

$$
\mathrm{CSRTOT}=\mathrm{CSRENV}+\mathrm{CSRSOC}
$$

\footnotetext{
7 In total, we analyzed 592 documents with a total of 88,469 report pages.
} 
Table 1 Keywords for the content analysis derived from the GRI framework

\begin{tabular}{ll}
\hline Keywords & \\
\hline Environmental & Social \\
\hline Recycled & Employment \\
Biodiversity & Employee turnover \\
Emissions & Collective bargaining \\
Effluents & Collective agreements \\
Waste & Occupational health \\
Spills & Occupational safety \\
Environmental impacts & Training \\
& Diversity \\
& Equal opportunities \\
& Human rights \\
& Discrimination \\
& Freedom of association \\
& Child labor \\
& Forced labor \\
& Compulsory labor \\
& Community \\
& Corruption \\
& Public policy \\
Compliance \\
Fines \\
Sanctions \\
Product responsibility \\
Customer health \\
Customer safety \\
\hline
\end{tabular}

CSRTOT is the total quantity of CSR disclosure, CSRENV is the amount of environmental disclosure, and CSRSOC the amount of social disclosure (i.e., the total number of keywords found in the analyzed reports). The three variables are identified for each of the companies by a summary of all the relevant reports' results in a specific year. For example: if a company provides an annual as well as a CSR report in a year, we summarize the content analysis results for both reports to achieve the total disclosure indexes for each company. Thus, the indexes reflect the number of hits when searching for all keywords in each category.

\subsection{Independent variables: determinants of CSR disclosure and control variables}

Company visibility (VISIBILITY) is closely related to the media attention a company receives. We measure visibility by counting the number of hits when searching for the companies' names ${ }^{8}$ on the Handelsblatt newspaper's website

\footnotetext{
${ }^{8}$ We use the companies' names as provided on the Deutsche Boerse AG website (2010).
} 
(Handelsblatt 2009). The Handelsblatt is the most important German newspapers in terms of business press with the highest impact due to its national coverage and its importance for investment communities. ${ }^{9}$

Profitability is measured by the ratio "return on invested capital" (ROIC) provided by Thomson One Banker. ${ }^{10}$ We use the freefloat in percentage of common shares (FREEFLOAT) as a measure for the companies' dispersion regarding its share ownership structure. This information was taken from the website of Deutsche Boerse (2010). We use the listing at a US stock exchange as an indicator of the companies' relationship with their US stakeholders ${ }^{11}$; a ' 1 ' indicates that the corresponding company is listed at a US stock exchange and ' 0 ' that it is not (USLISTED). We obtained this information from the companies' websites or by directly contacting the relevant company.

We used the classification provided by Deutsche Boerse (2010) to classify the sample companies into 18 industries (see Table 6 in the Appendix); dummy variables are used to distinguish between industries. We employ two measures for the companies' size, as we expect them to affect the disclosure activities in the different CSR categories: the number of employees (EMPLOYEES) and the amount of total assets (TOTASSETS). The number of employees in each year and company is available on the Deutsche Boerse AG website (Deutsche Boerse 2010); we assume that this measure is likely to be associated with social disclosures. The amount of total assets is available from Thomson One Banker (Thomson One Banker 2009); as total assets may be a proxy for environmental impact, it is likely that this measure is associated with environmental disclosures. ${ }^{12}$ Table 2 offers a summary of the data sources, the dependent and independent variables, and abbreviations.

\subsection{Regression analysis}

We use a Probit estimation for models that have CSRR as a dependent variable. This provides a consistent estimation of the probability that the binary dependent variable will have a value of one (i.e., that the firm provides a CSR report) contingent upon the independent variables. We use ordinary least squares regressions for models that have CSR disclosure levels as dependent variables (CSRTOT, CSRENV and CSRSOC). We estimate our models as described below:

\footnotetext{
9 To validate the VISIBILITY measure, we repeated the previously described analysis in respect of the Financial Times Deutschland and the Wall Street Journal. The correlation analysis indicates that the three visibility measures are closely correlated, adding to our measure's validity.

${ }^{10}$ According to Thomson One Banker, ROIC is calculated as follows: ROIC = (Net Income before Preferred Dividends + Interest Expense on Debt - Interest Capitalized $) /(($ Last Year's Total Capital + Last Year's Short Term Debt and Current Portion of Long Term Debt) + (Current Year's Total Capital + Current Year's Short Term Debt and Current Portion of Long Term Debt)/2) * 100.

11 Alternatively, we could have used sales in the US as a proxy. We decided to use US stock listing as the literature (e.g., Bancel and Mittoo 2001) suggests that foreign listings are key for increasing visibility, prestige and image in other markets, for growth of the shareholder base/appeal to foreign investors, and for implementing a global strategy. Thus, we consider the US listing as a proxy for US stakeholders' involvement.

12 Companies with high total assets are generally from the manufacturing and energy supplying industry.
} 


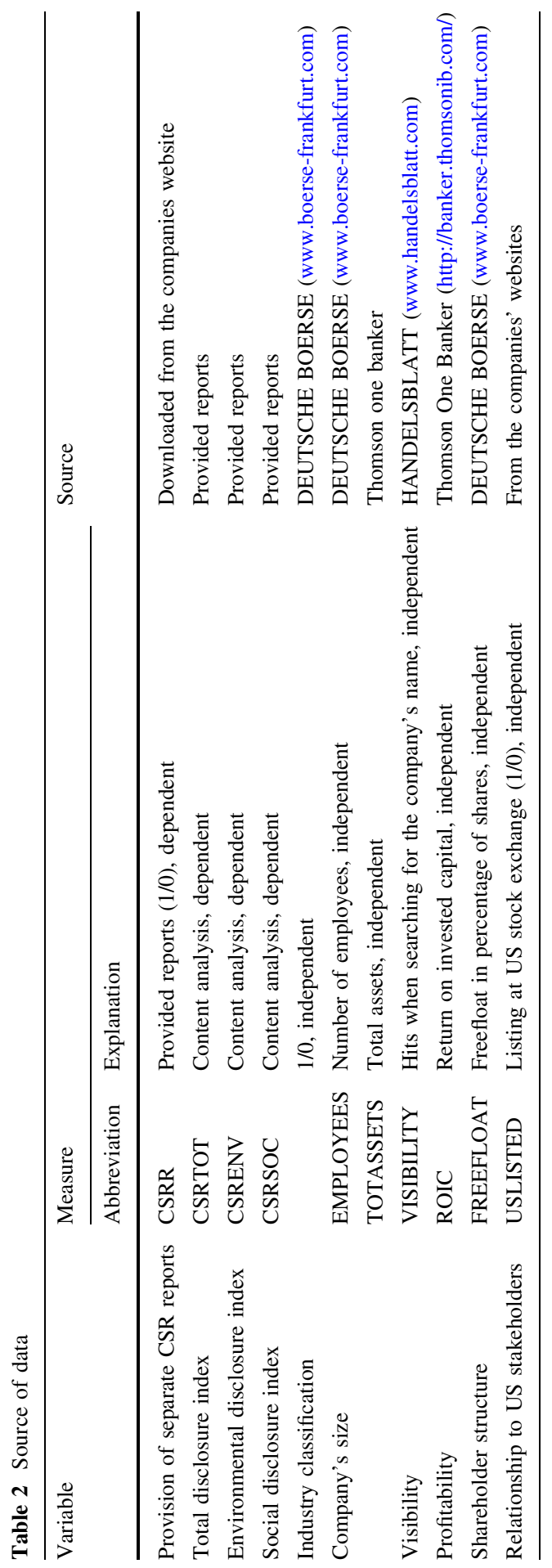




\section{$\mathrm{CSRR}=\mathrm{f}($ VISIBILITY, ROIC, FREEFLOAT, USLISTING, IND, SIZE, YR $)$}

respectively

$$
\mathrm{CSRDISC}=\mathrm{f}(\text { VISIBILITY, ROIC, FREEFLOAT, USLISTING, IND, SIZE, YR) }
$$

where, CSRR, CSR report variable (' 1 ' if the company produces a CSR report, '0' otherwise); CSRDISC, CSR Disclosure index extracted by means of content analysis (for respectively CSRTOT, total amount of disclosure; CSRENV, total amount of environmental disclosures; and CSRSOC, total amount of social disclosures); VISIBILITY, Number of hits found for the companies' names at www.handelsblatt.com; ROIC, Profitability measured by return on invested capital; FREEFLOAT, Shareholder structure by percentage of common shares in the freefloat; USLISTING, Relationship with US stakeholders measured by means of the US listing (yes or no); IND, Industry dummies for 18 industries, respectively ('BANKS' is the benchmark); SIZE, Size, measured by the number of employees or by the amount of total assets, respectively; YR, Year dummies for 2007-2009, respectively (2006 is the benchmark).

\section{Results and discussion}

\subsection{Descriptive statistics and correlations}

Table 3 indicates that the dispersion of most variables is on an acceptable level. To reduce skewness and kurtosis, we take the log of the variables EMPLOYEES and TOTASSETS (labeled ' $\operatorname{logEMPL}$ ' and ' $\log$ TA').

The results of our content analysis show that the amount of CSR disclosure is increasing over time (see Fig. 1). The number of CSR reports that the companies in our sample provide (CSRR) increased from 14 in 2006 to 26 in 2009. The total disclosure index (CSRTOT) increased from 10,050 hits in 2006 to more than 21,650 hits in 2009. ${ }^{13}$ This development is displayed in Fig. 1, which also divides the total disclosure index into social and environmental disclosures. Our findings are consistent with most other studies on CSR disclosure (e.g., Gray et al. 2001; Kolk 2005; Matten and Moon 2008). They suggest that (German) companies are increasingly becoming aware of CSR disclosures' positive effects on their political costs.

Table 4 shows the Pearson correlations for the disclosure indexes, the independent variables, and the control variables. The correlations between the independent variables provide no indication of multicollinearity, as no bivariate correlation exceeds the value of 0.9 (Cheng et al. 2007; Farrar and Glauber 1967; Hair et al. 2010; Peng and Beamish 2008; Roberts 1992). ${ }^{14}$

\footnotetext{
13 Over the same period, the average number of pages in the analyzed reports increased from 160 in 2006 to 204 in 2009 (per company-year observation).

14 However, in order to ensure that there is no multicollinearity, we performed an additional test by calculating the variance inflation factor (VIF) for all the variables where the bivariate correlations exceed the value of 0.5. The results indicate that all VIF factors are well below the tolerance values of 10, indicating that multicollinearity is not an issue in our analyses (Hair et al. 2010; Roberts 1992).
} 


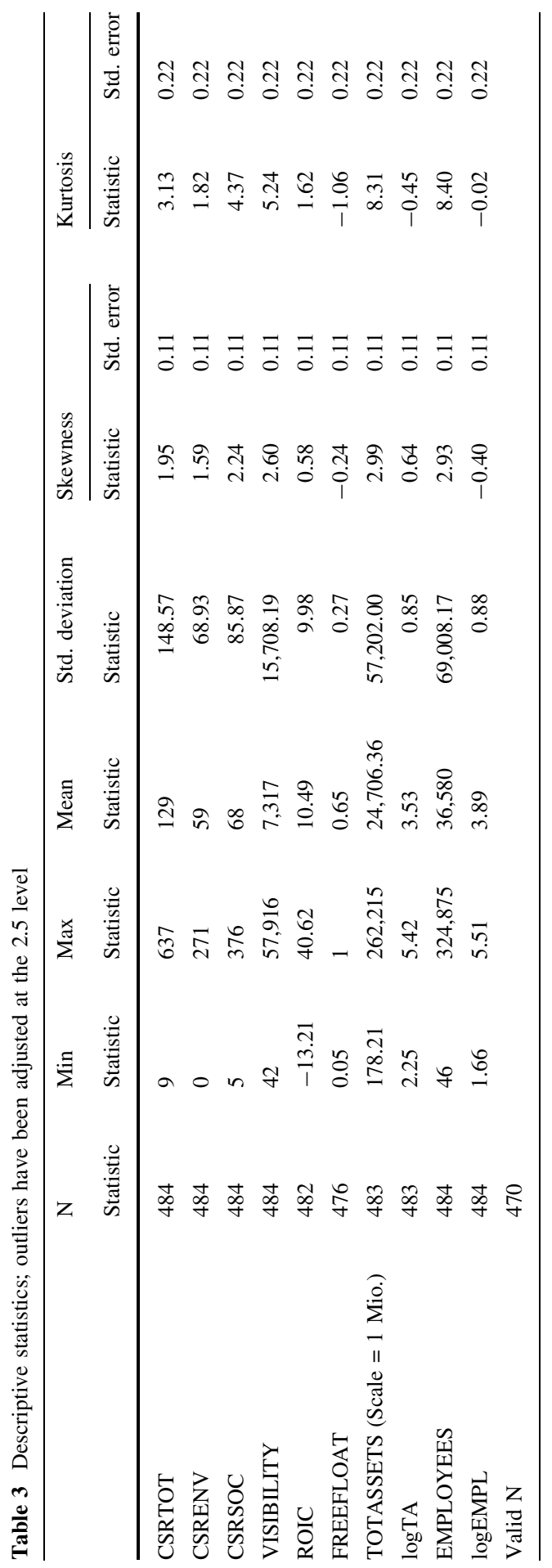



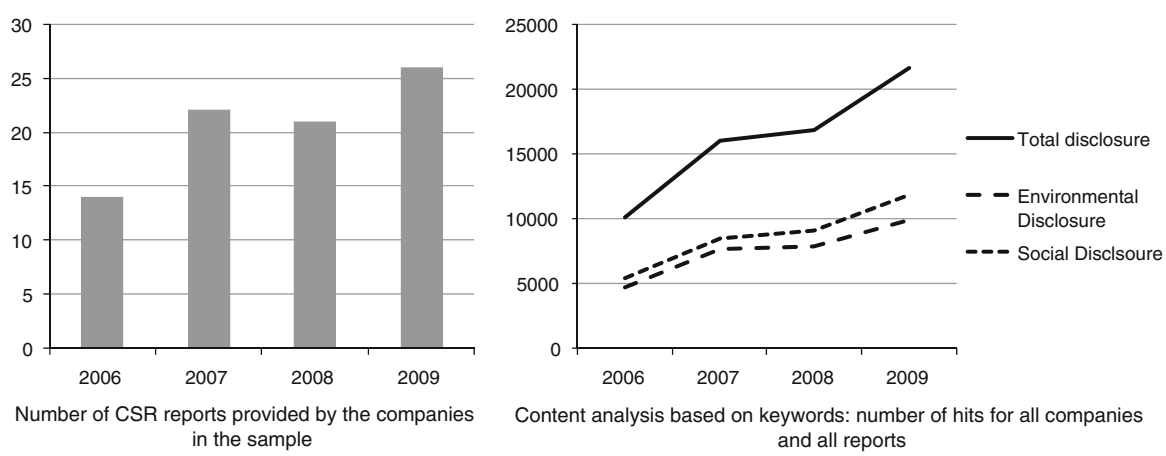

Fig. 1 Descriptive results of the content analysis

With the exception of the profitability measure, the correlation matrix reveals a positive interrelation between all the disclosure indices and the independent variables, which is consistent with our hypotheses. Firm size is also associated with all the disclosure indices. Furthermore, the Pearson correlations reveal strong industry effects, as companies from "polluting industries" (e.g., CHEMI, UTILI, and AUTOM) disclose a great deal of CSR information.

\subsection{Regression analysis}

While the descriptives and correlation analysis provide some insights into the average level and the univariate relations between the variables, we are interested in their joint effects. We applied regression analysis to estimate these effects, using the disclosure indices as the dependent variables. Table 5 presents our main results.

The results in Table 5 are mostly in line with our hypotheses. Consistent with H1 is that the companies' visibility is positively associated with CSR disclosure ( $\mathrm{p}<0.10$ for all dependent variables). Our second hypothesis is only partially confirmed: profitability is associated with more environmental disclosures ( $p<0.10)$, but this doesn't affect the total or social disclosures $(p>0.10)$. H3 is confirmed by our results: the shareholder structure determines CSR disclosures. Thus, the higher the percentage of freefloat, the more a company discloses information on its social and environmental performance. Finally, a company's relationship with US stakeholders $(\mathrm{H} 4)$ affects all the disclosure indices $(\mathrm{p}<0.10)$ : companies apparently adjust their disclosure practices when they operate in distinctively different business environments.

Consistent with some earlier work (e.g., Brammer and Pavelin 2006; Roberts 1992), our models provide evidence of a significant systematic variation across industries regarding their propensity to make CSR disclosures. In particular, we find that companies from so-called "polluting sectors" provide more information on environmental issues (such as the automobile, basic resources, chemical, construction, transportation/logistics industries; all $\mathrm{p}<0.10$ ). These companies have a long 


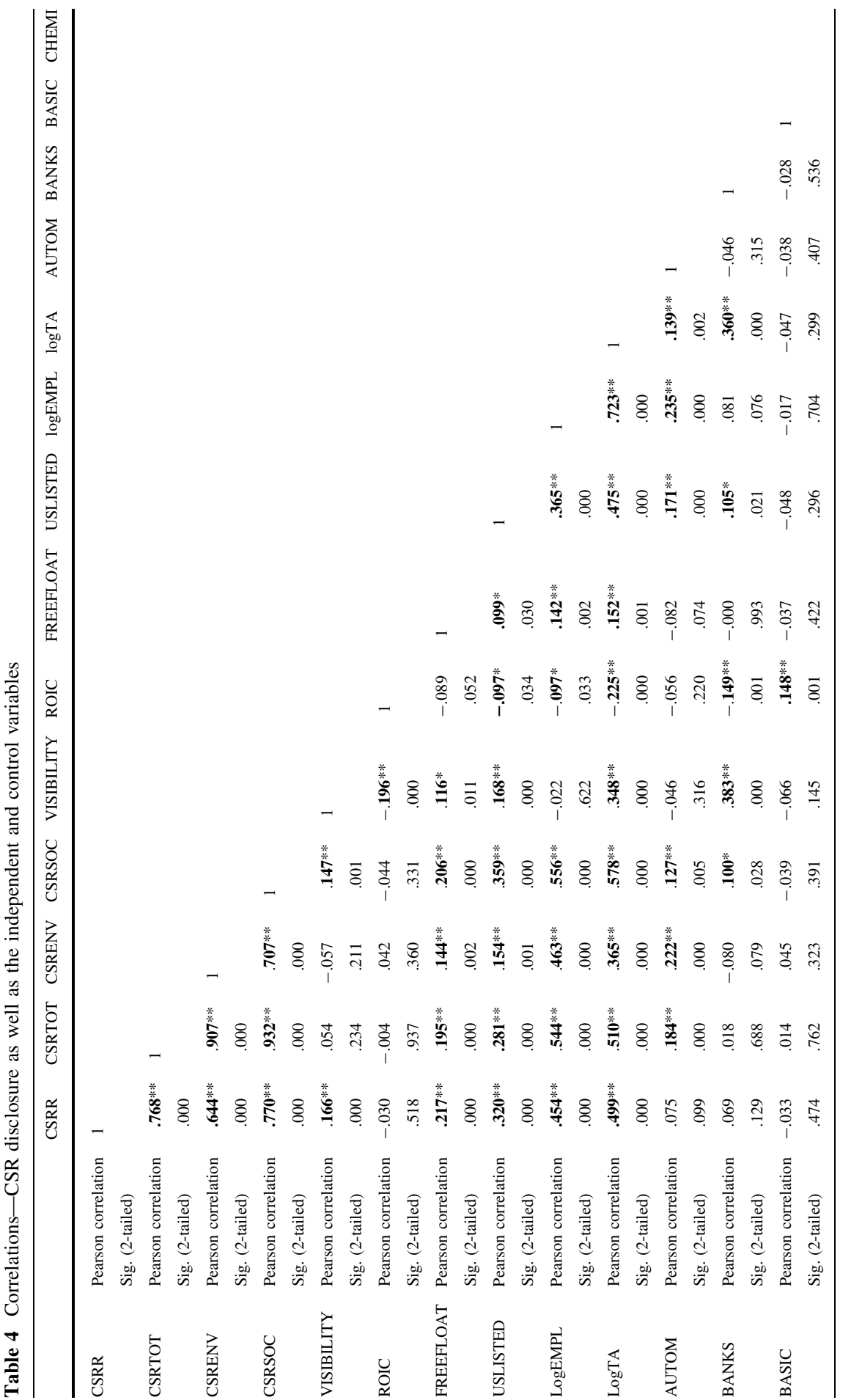




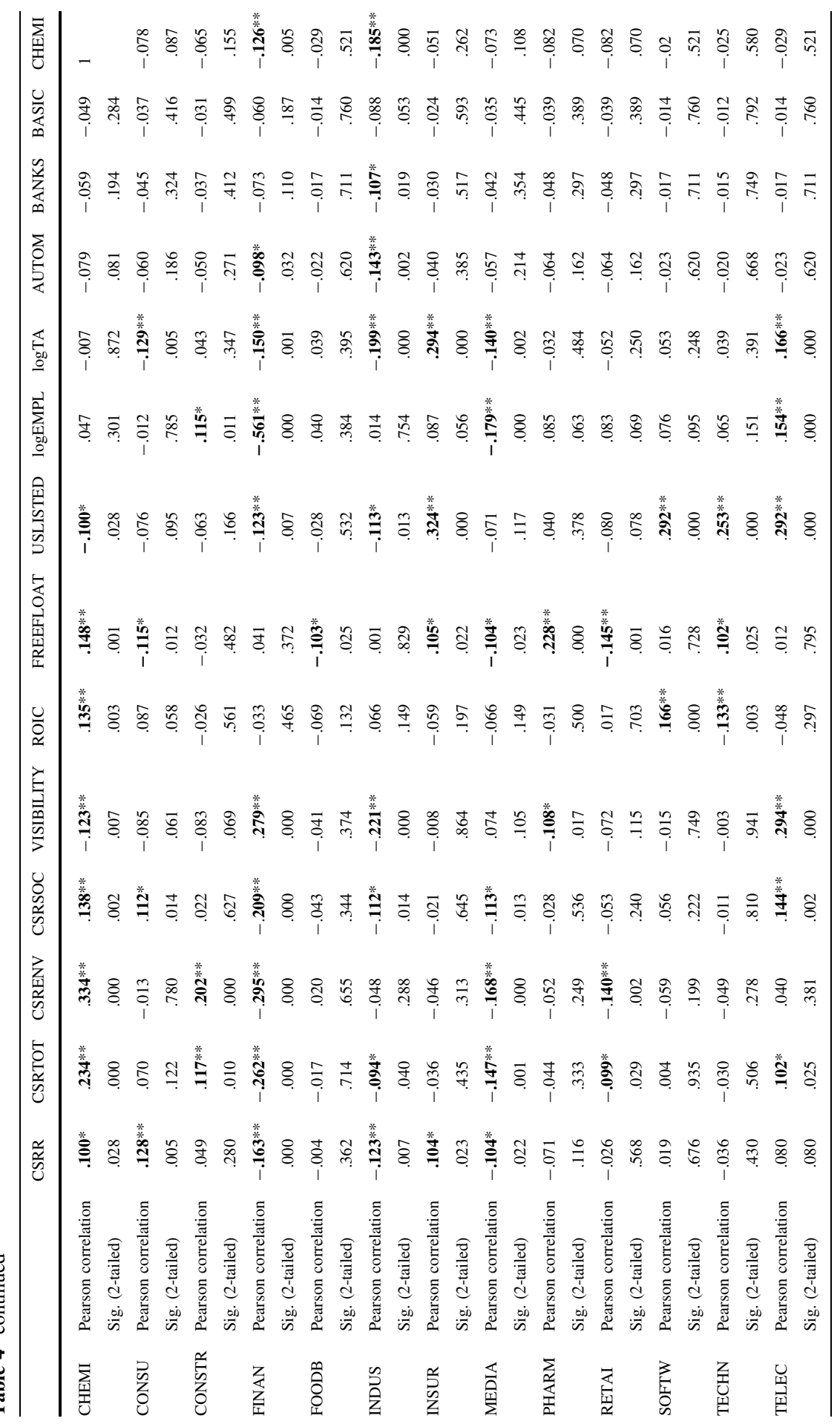




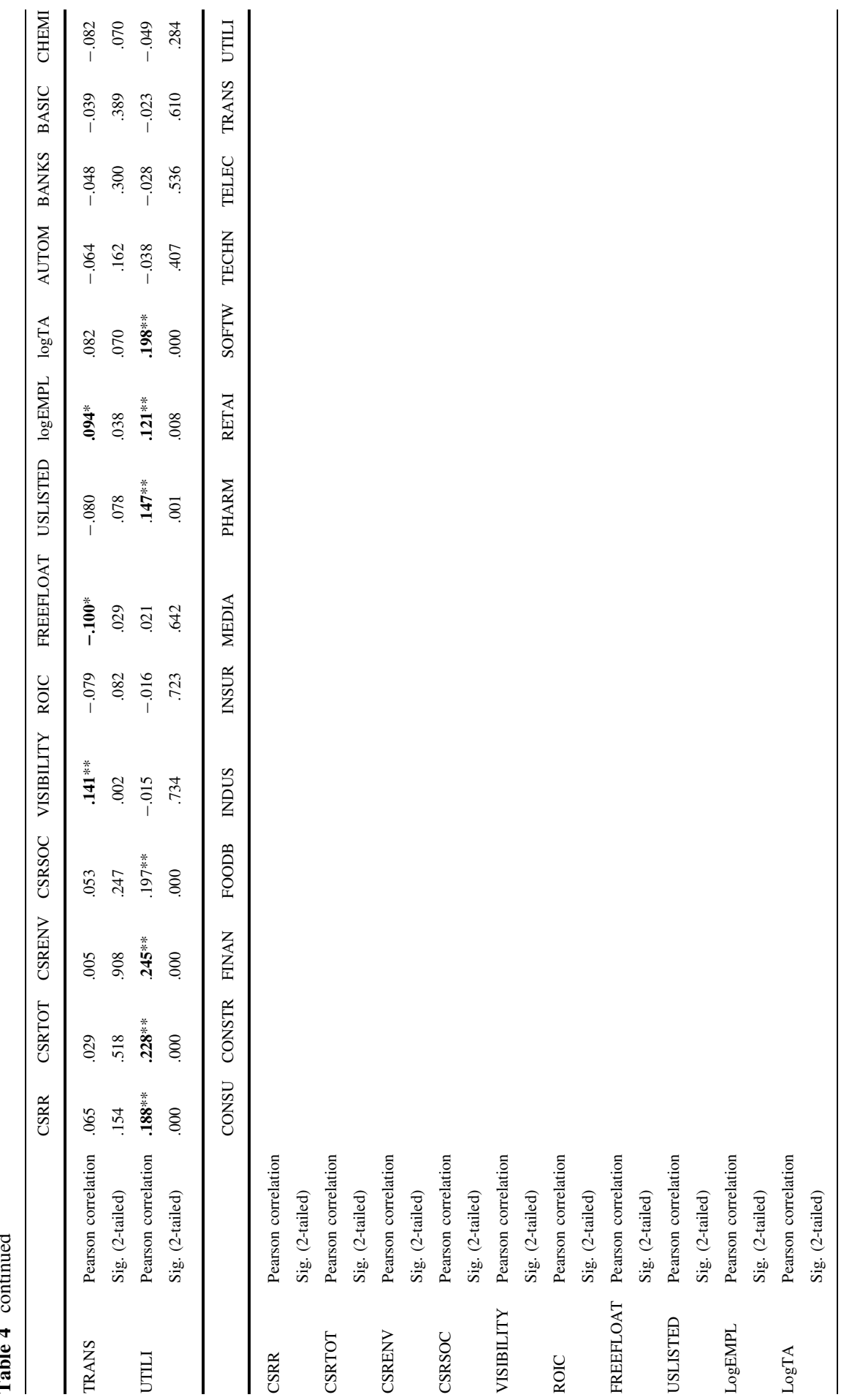




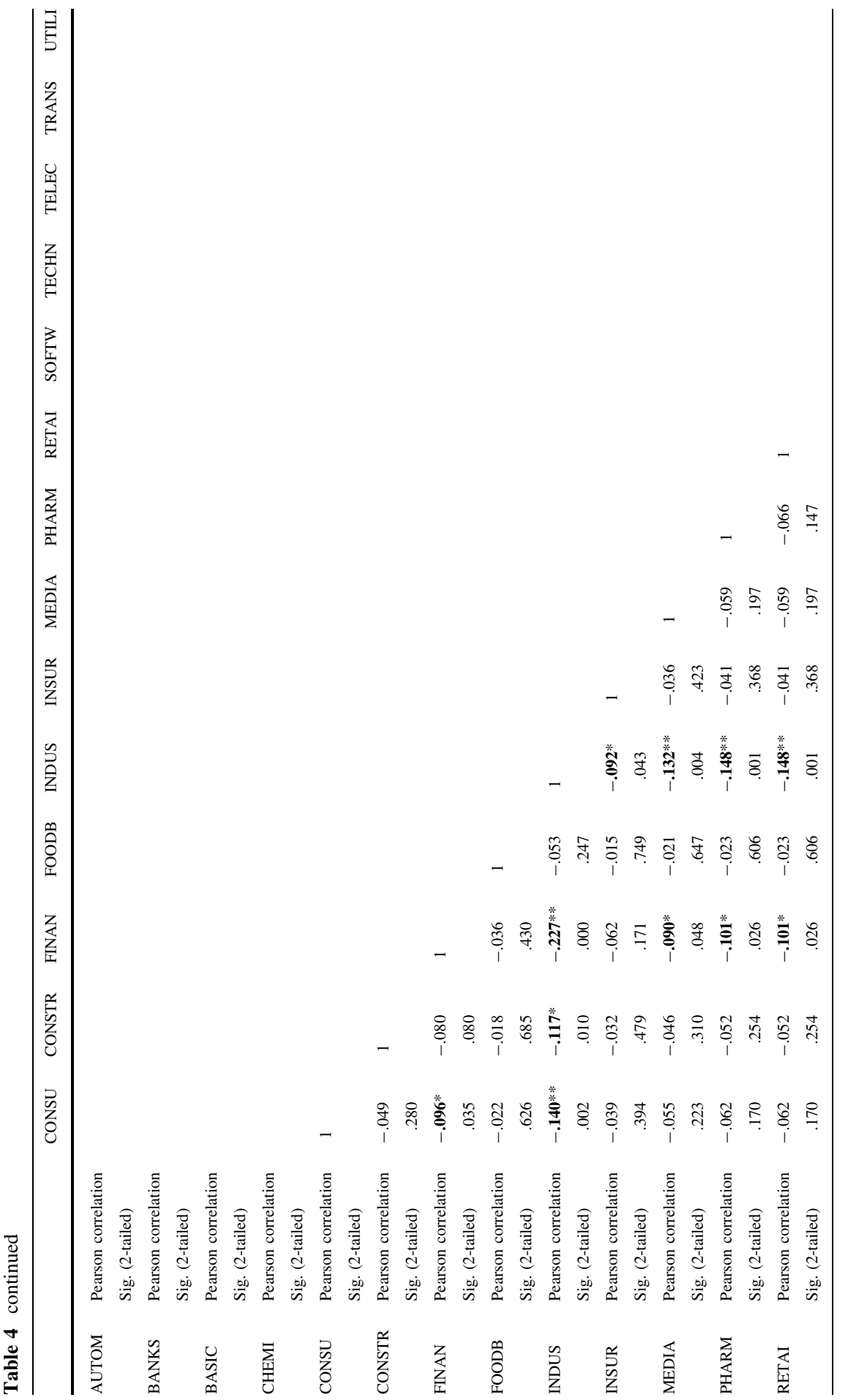




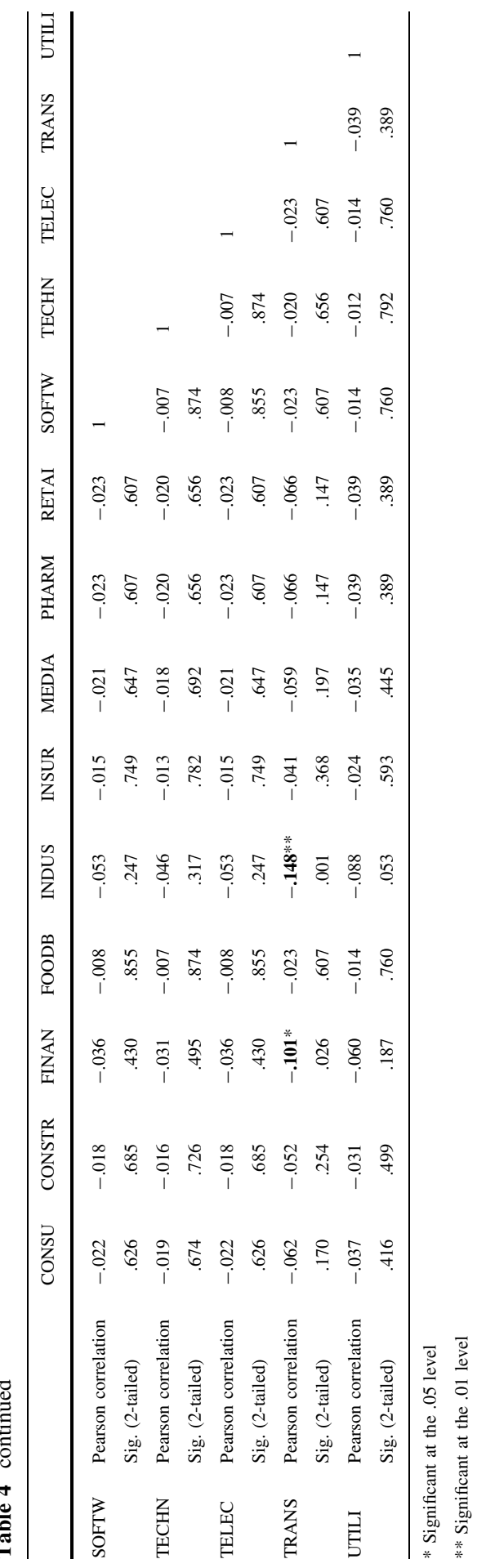




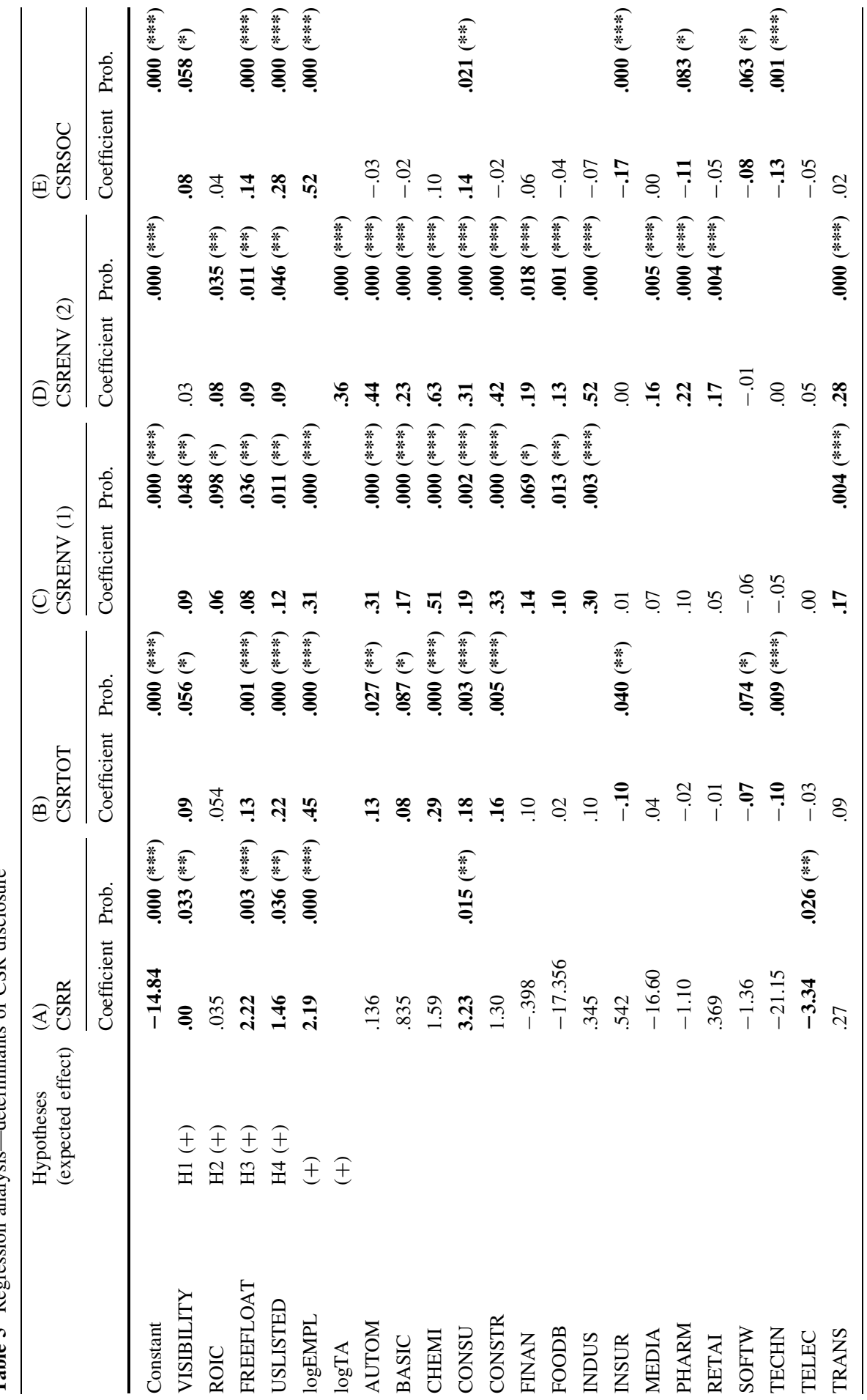




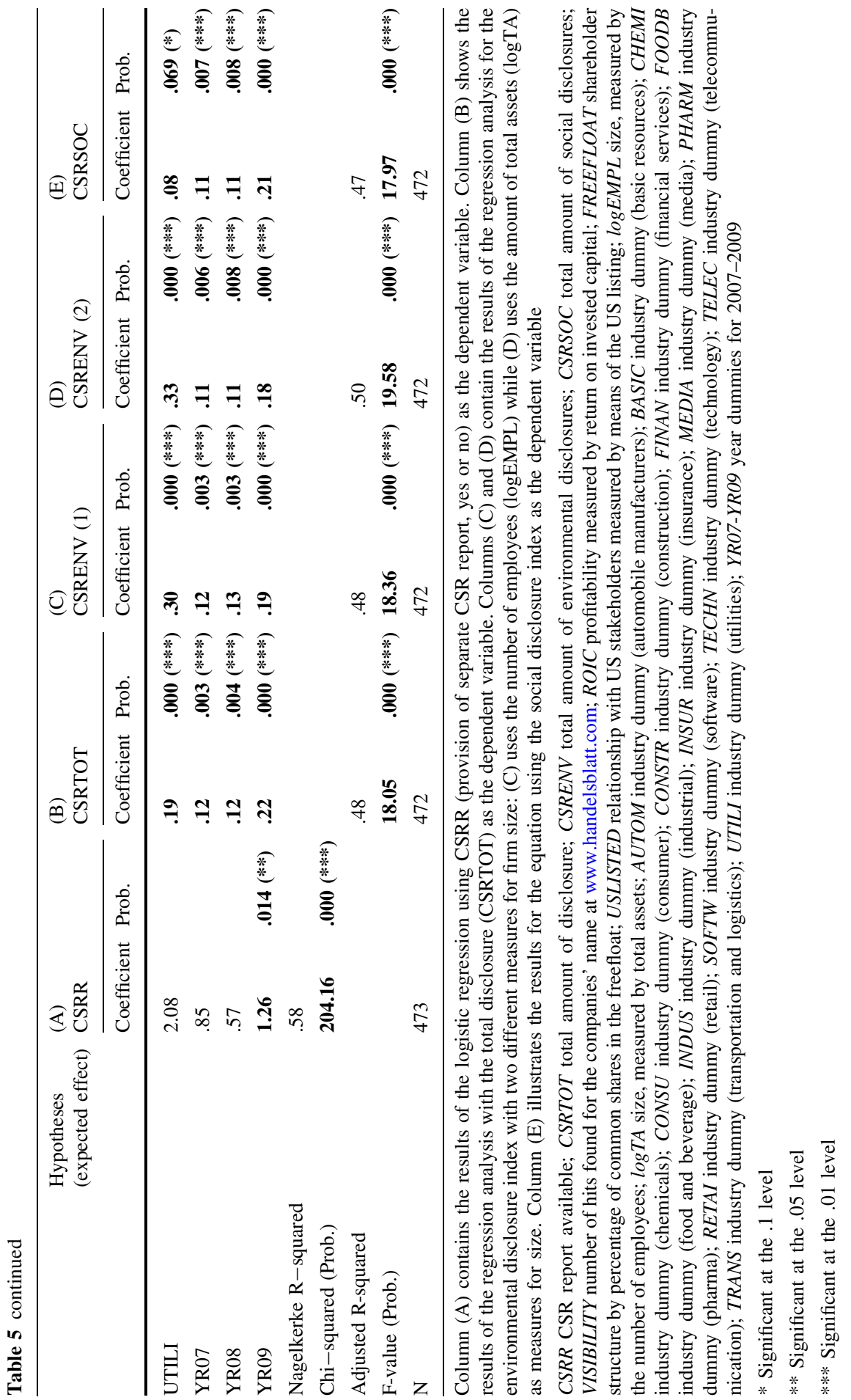


tradition of (and experience with) CSR campaigns, as they have been confronted with powerful stakeholders from the environmental movement since the early 1980s. Accordingly, they proactively disclose much information on their environmental performance to reduce the possible political costs arising from their despised activities (Deegan and Gordon 1996; Meek et al. 1995).

Companies from the consumer industry and the energy supplying industries disclose more information on all CSR aspects. As consumer industry companies normally have an exposed public position (most of them sell their goods to end consumers), they have strong incentives to reduce their political costs through CSR disclosures. Companies from energy supplying industries may face all kinds of external pressure groups as a result of the nuclear power debate in Germany; this may have pressured them to disclose more CSR information.

Companies in the service sector (such as insurance, software, and the technology industry) generally tend to disclose less CSR information $(\mathrm{p}<0.10)$. While this is understandable given their lower environmental impact, it is rather surprising that companies in these industries also provide less information on social issues, if one considers that their employees are likely to be a key asset. One reason for this apparent lack of disclosure may be that the keywords we used relate to issues that are more salient in production industries (e.g., occupational health and safety, product responsibility).

The results also show that a company's size (specifically, the number of employees) affects CSR disclosures $(\mathrm{p}<0.10)$. In addition, the amount of total assets $(\log$ TA) affects environmental disclosure. This finding may be due to industry effects, since, in general, companies with high total assets belong to polluting industries.

Our findings are mostly consistent with certain earlier works on environmental disclosures in other countries (e.g., Chen and Bouvain 2009; Brammer and Pavelin 2006) and on executive pay disclosures in Germany (e.g., Chizema 2008). In addition, our results are also largely consistent with our hypotheses derived from political cost theory, which suggests that companies disclose information to reduce potential regulation and taxation (Watts and Zimmermann 1978). However, our findings also suggest that environmental and social disclosures are driven by somewhat different stakeholder groups as reflected in different firm characteristics. For example, firms in "polluting sectors" tend to have relatively high levels of environmental disclosure, but similar levels of social disclosure. This may reflect pressures from different stakeholder groups: firms in "polluting sectors" may be monitored by environmental groups, while firms in consumer sectors may be more closely monitored by consumer groups. Similarly, firm profitability is associated with higher environmental disclosures but not with social disclosures. This may be due to historical developments: companies in "polluting industries" have been confronted with powerful stakeholders for a long time, while Western consumers only seem to have been concerned with labor practices since the latter part of the 1990s (Islam and Deegan 2010). Longitudinal studies may provide more insight into these issues. 


\section{Summary and conclusions}

Economists have for long tried to determine the reasons for companies voluntarily disclosing information on environmental and social aspects. We rely on the political cost theory (Watts and Zimmermann 1978) to argue that companies report on CSR for economic reasons: they try to reduce their political costs by providing information on their social responsibility (Fields et al. 2001). Even though some researchers argue that the political cost hypothesis does not fully and satisfactorily explain the reasons for voluntary (CSR) disclosure (Milne 2002), we believe that its assumption provides at least some explanation for companies voluntarily disclosing CSR information.

We identify a number of firm-specific factors which are likely to act as proxies for political costs and, as such, are likely to be related to a company's willingness to voluntarily disclose CSR information. On the basis of the GRI framework's core indicators, we apply content analysis to detect the amount and content of CSR information provided by the 130 largest listed companies in Germany.

Our results show that CSR disclosure is positively associated with higher company visibility, a more dispersed shareholder ownership structure, and US cross-listing (a proxy for US stakeholders' interest in the company). Profitability only affects CSR disclosure's environmental dimension. Furthermore, our results show that CSR disclosure is affected by industry membership and firm size: companies from "polluting industries" tend to have a higher level of environmental disclosures. Finally, big companies disclose more than small companies.

These results are mostly consistent with the political cost theory, from which we derive our hypotheses. That is, firms appear to disclose CSR information to reduce the potential impact of additional regulation, taxes, and other activities that may negatively affect the firm's value. Failure to remove informational asymmetries (i.e., lower disclosure) may result in more occupational safety regulations, higher anti-pollution taxes, and consumer boycotts that may reduce the firm's value.

Our results also suggest that there are some differences in the disclosure dimensions: environmental disclosures appear to be driven by somewhat different firm characteristics than social disclosures. A potential reason is that these factors relate to different stakeholder groups; for example, environmental stakeholder groups may emphasize environmental disclosure while consumer groups may emphasize labor practices. Over time, societal expectations regarding what is considered "appropriate behavior" may evolve; consequently, CSR disclosures may also evolve over time as different stakeholder groups gain or lose power. One avenue that further research could explore is different stakeholder groups' rise and fall, and the disclosure practices of companies responding to these dynamics in their stakeholder environment.

As with all empirical studies, this study is subject to limitations. First of all, the industry classification is open to criticism, as some industries are represented by only three or fewer companies. Second, since only one country is researched, the cultural aspects can't be generalized. Third, content analysis also has its limitations: using keywords as units of analysis may be an inappropriate methodology, as these words are detached from their textual background. While we account for unusual 
scores in some reports, our results may have been affected by our methodology. Finally, deriving the keywords for the content analysis from the GRI guidelines is not free of risk, as the guidelines might not capture all of the relevant CSR aspects (Moneva et al. 2006).

Despite these limitations, we believe that our results provide interesting insights into the determinants of CSR disclosure. In addition to the limitations mentioned previously, there are other opportunities in the field of CSR disclosure. For example, a broader set of variables that can act as proxies for other stakeholder groups could be considered as possible determinants of CSR disclosure. On the other hand, the receivers of information have to be integrated into the research in order to analyze the linkage between neo-classical theory and CSR disclosure. That is, the effects of the disclosed information on the companies' stakeholders, in general, and their shareholders, in particular, need to be examined.

\section{Appendix}

See Table 6.

Table 6 Number of companies per industry sector (according to Deutsche Boerse 2010)

\begin{tabular}{llc}
\hline Industry-sector & Abbreviation & $\begin{array}{c}\text { Number of } \\
\text { companies }\end{array}$ \\
\hline Automobile manufacturers & AUTOM & 7 \\
Banks & BANKS & 4 \\
Basic resources & BASIC & 3 \\
Chemicals & CHEMI & 12 \\
Construction & CONSTR & 5 \\
Consumer & CONSU & 8 \\
Financial services & FINAN & 19 \\
Food and beverage & FOODB & 1 \\
Industrial & INDUS & 32 \\
Insurance & INSUR & 3 \\
Media & MEDIA & 6 \\
Pharma & PHARM & 8 \\
Retail & RETAI & 8 \\
Software & SOFTW & 1 \\
Technology & TECHN & 1 \\
Telecommunication & TELEC & 1 \\
Transportation and logistics & TRANS & 8 \\
Utilities & UTILI & 3 \\
Total & & \\
\hline & & 130 \\
\hline & & \\
\hline
\end{tabular}


Open Access This article is distributed under the terms of the Creative Commons Attribution Noncommercial License which permits any noncommercial use, distribution, and reproduction in any medium, provided the original author(s) and source are credited.

\section{References}

Abdolmohammadi MJ (2005) Intellectual capital disclosure and market capitalisation. J Intellect Cap 6:397-416

Agle BR, Mitchell RK, Sonnenfeld JA (1999) Who matters to CEO's? An investigation of stakeholder attributes and salience, corporate performance, and CEO values. Acad Manag J 42:507-525

Aupperle G, Carrol A, Hatfield J (1985) An empirical examination of the relationship between corporate social responsibility and profitability. Acad Manag J 22:501-515

Ball RJ, Foster G (1982) Corporate financial reporting: a methodological review of empirical research. J Account Res 20:161-234

Bancel F, Mittoo UR (2001) European managerial perceptions of the net benefits of foreign stock listings. Eur Finan Manag 7(2):213-236

Belkaoui A, Karpik PG (1989) Determinants of the corporate decision to disclose social information. Account Audit Account J 2(1):36-51

Bewley K, Li Y (2000) Disclosure of environmental information by Canadian manufacturing companies: a voluntary disclosure perspective. Adv Environ Account Manag 1:201-226

Blacconiere WG, Patten DM (1994) Environmental disclosures, regulatory costs, and changes in firm value. J Account Econ 18:357-377

Bowen HR (1953) Social responsibilities of the businessman. Harper and Row, New York

Brammer S, Millington A (2006) Firm size, organizational visibility and corporate philanthropy: an empirical analysis. Bus Ethics Eur Rev 15(1):6-18

Brammer S, Pavelin S (2006) Voluntary environmental disclosures by large UK companies. J Bus Finan Account 33(7 and 8):1168-1188

Callens I, Tyteca D (1999) Towards indicators of sustainable development for firms: a productive efficiency perspective. Ecol Econ 28(1):41-53

Campbell D (2004) A longitudinal and cross-sectional analysis of environmental disclosure in UK companies-a research note. Br Account Rev 36:107-117

Carroll AB (1999) Corporate social responsibility-evolution of a definitional construct. Bus Soc $38(3): 268-295$

Carroll AB (2006) Corporate social responsibility: a historical perspective. In: Epstein MJ, Hanson KO (eds) The accountable corporation: corporate social responsibility, 3rd edn. Praeger, Westport, pp 3-30

Chau GK, Gray SJ (2002) Ownership structure and corporate voluntary disclosure in Hong Kong and Singapore. Int J Account 27:247-265

Chen S, Bouvain P (2009) Is corporate responsibility converging? A comparison of corporate responsibility reporting in the USA, UK, Australia, and Germany. J Bus Ethics 87:299-317

Chen S, Chen X, Cheng Q (2008) Do family firms provide more or less voluntary disclosure? J Account Res 46(3):499-536

Cheng MM, Luckett PF, Mahama H (2007) Effect of perceived conflict among multiple performance goals and goal difficulty on task performance. Account Finan 47:221-242

Chizema A (2008) Institutions and voluntary compliance: the disclosure of individual executive pay in Germany. Corp Gov 16(4):359-374

Cho CH, Roberts RW, Patten DM (2009) The language of US corporate environmental disclosure. Account Organ Soc. doi:10.1016/j.aos.2009.10.002

Cormier D, Gordon IM (2001) An examination of social and environmental reporting strategies: determinants, costs and benefits. Account Audit Account J 14:587-616

Cowen SS, Ferreti LB, Parker LD (1987) The impact of coprorate characteristics on responsibility disclosure: a typology and frequency-based analysis. Account Organ Soc 12(3):111-122

Crane A, Matten D (2007) Editor's introduction. Corporate social responsibility as a field of scholarship. In: Crane A, Matten D (eds) Corporate social responsibility. Volume 1: theories and concepts of corporate social responsibility. Sage Publications, London, pp xvi-xxx 
De Bakker F, Groenewegen P, Den Hond F (2005) A Bibliometric analysis of 30 years of research and theory on corporate social responsibility and corporate social performance. Bus Soc 44(3):283-317

Deegan C, Carroll G (1993) An analysis of incentives for australian firms to apply for reporting excellence awards. Account Bus Res 26(3):219-227

Deegan C, Gordon B (1996) A study of the environmental disclosure practices of Australian corporations. Account Bus Res 26(3):187-199

Déjean F, Martinez I (2009) Environmental disclosure and the cost of equity: the French case. Account Eur 6(1):57-80

Deutsche Boerse (2010) Website of Deutsche Boerse AG. http://www.boerse-frankfurt.com. Accessed Feb 2010

Donaldson T, Preston L (1995) The stakeholder theory of the corporation: concepts, evidence, implications. Acad Manag Rev 20(1):65-91

Dowling J, Pfeffer J (1975) Organizational legitimacy: social values and organizational behaviour. Pac Sociol Rev 18(1):122-136

Drucker PF (1984) The new meaning of corporate social responsibilities. Calif Manage Rev 26(2):53-63

Dye RA (1985) Disclosure of nonproprietary information. J Account Res 23(1):123-145

Fama EF, Jensen MC (1983) Separation of ownership structure and control. J Law Econ 26(2):301-325

Farrar D, Glauber R (1967) Multicollinearity in regression analysis the problem revisited. Rev Econ Stat 49(1):92-107

Fields TD, Lys TZ, Vincent L (2001) Empirical research on accounting choice. J Account Econ 31:255-307

Freeman RE (1984) Strategic management: a stakeholder approach. Pitman, Boston

Friedman M (1962) Capitalism and freedom. University of Chicago Press, Chicago

Friedman M (2007) The social responsibility of business is to increase its profits. In: Crane A, Matten D (eds) Corporate social responsibility. Volume 1: theories and concepts of corporate social responsibility. Sage Publications, London, pp 69-74

Frooman J (1999) Stakeholder influence strategies. Acad Manag Rev 24(2):191-205

Ghazali NAM (2007) Ownership structure and corporate social responsibility disclosure: some Malaysian evidence. Corp Gov 7(3):251-266

Gladwin TN, Kennelly JJ, Krause T-S (1995) Shifting paradigms for sustainable development: implications for management theory and research. Acad Manag Rev 20:874-907

Godfrey PC (2005) The relationship between corporate philanthropy and shareholder wealth: a risk management perspective. Acad Manag Rev 30:777-798

Gray R, Kouhy R, Lavers S (1995a) Corporate social and environmental reporting: a review of the literature and a longitudinal study of UK disclosure. Account Audit Account J 8(2):47-77

Gray R, Kouhy R, Lavers S (1995b) Constructing a research database of social and environmental reporting by UK companies. Account Audit Account J 8(2):78-101

Gray R, Javad M, Power DM, Sinclair CD (2001) Social and environmental disclosure and corporate characteristics: a research note and extension. J Bus Finance Account 28(3 and 4):327-356

GRI (2010) Website of global reporting initiative. http://www.globalreporting.org. Accessed Dec 2009

Guthrie J, Farneti F (2008) GRI sustainability reporting by Australian public sector organizations. Public Money Manag 28(6):361-366

Guthrie J, Parker LD (1989) Corporate social reporting: a rebuttal of legitimacy theory. Account Bus Res 19:343-352

Guthrie J, Petty R, Yongvanich K, Ricceri F (2004) Using content analysis as a research method to inquire into intellectual capital reporting. J Intellect Cap 5:282-293

Guthrie J, Cuganesan S, Ward L (2008) Industry specific social and environmental reporting: the Australian food and beverage industry. Account Forum 32:1-15

Hair JF, Black WC, Babin BJ, Anderson RE (2010) Multivariate data analysis. A global perspective. Pearson, Upper Saddle River

Han JCY, Wang SW (1998) Political costs and earnings management of oil companies during the 1990 Persian Gulf crisis. Account Rev 73:103-117

Handelsblatt (2009) Website of handelsblatt newspaper. http://www.handelsblatt.com. Accessed March 2010

Healy PM, Palepu KG (2001) Information asymmetry, corporate disclosure, and the capital markets: a review of the empirical disclosure literature. J Account Econ 31(1-3):405-440

Holder-Webb L, Cohen JR, Nath L, Wood D (2008) The supply of corporate social responsibility disclosures among U.S. firms. J Bus Ethics 84:497-527 
Holsti OR (1969) Content analysis for the social sciences and humanities. Addison-Wesley, Reading

Holthausen RW, Leftwich RW (1983) The economic consequences of accounting choice. J Account Econ 5:77-117

Husted BW, Salzar J (2006) Taking Friedman seriously: maximizing profits and social performance. J Manag Stud 43(1):75-91

Islam MA, Deegan C (2010) Media pressures and corporate disclosure of social responsibility performance: a case study of two Global clothing and sports retail companies. Account Bus Res 40(2):131-148

Jensen MC, Meckling WH (1978) Can the corporation survive? Finan Analysts J 34:31-37

Kolk A (2005) Environmental reporting by multinationals from the Triad: convergence or divergence. Manag Int Rev 45(1):145-167

Kolk A, Walhain S, Van de Wateringen S (2001) Environmental reporting by the fortune global 250: exploring the influence of nationality and sector. Bus Strategy Environ 10:15-28

Krippendorff K (2004) Content analysis: an introduction to its methodology. Sage Publications, London

Langlois CC, Schlegelmilch BB (1990) Do corporate codes of ethics reflect national character? Evidence from Europe and the United States. J Int Bus Studies 21(4):519-539

Lijphart A (1984) Democracies: patterns of majoritarian and consensus government in twenty-one countries. Yale University Press, New Haven

Lynch B (2009) An examination of environmental reporting by Australian state government departments. Accounting forum. doi:10.1016/j.accfor.2009.11.001

Lyon TP, Maxwell JW (2006) Greenwash: corporate environmental disclosure und threat of audit. Ross school of business working paper series, Working paper no. 1055. http://ssrn.com/abstract=938988

Lyon TP, Maxwell JW (2007) Corporate social responsibility and the environment: a theoretical perspective. Working paper series. http://ssrn.com/abstract=1011793

Maignan I, Ralston DA (2002) Corporate social responsibility in Europe and the US: insights from businesses' self-representations'. J Int Bus Studies 33(3):497-514

Matten D, Moon J (2008) "Implicit" and "explicit" CSR: a conceptual framework for a comparative understanding of corporate social responsibility. Acad Manag Rev 33:404-424

McWilliams A, Siegel D (2001) Corporate social responsibility: a theory of the firm perspective. Acad Manag Rev 26(1):117-127

Meek GK, Roberts CB, Gray AJ (1995) Factors influencing voluntary annual report disclosures by US, UK and continental European multinational corporations. J Int Bus Studies 26(3):555-572

Milne MJ (2002) Positive accounting theory, political costs and social disclosure analyses: a critical look. Critical Perspect Account 13:369-395

Mitchell RK, Agle BR, Wood DJ (1997) Toward a theory of stakeholder identification and salience: defining the principles of who and what really counts. Acad Manag Rev 22:853-886

Moneva JM, Archel P, Correa C (2006) GRI and the camouflaging of corporate unsustainability. Account Forum 30:121-137

Neuendorf KA (2002) The content analysis guidebook. Sage Publications, London

Patten DM (1991) Exposure, legitimacy, and social disclosure. J Account Public Policy 10:297-308

Peng GZ, Beamish PW (2008) The effect of national corporate responsibility environment on Japanese foreign direct investment. J Bus Ethics 80:677-695

Powell WW (1991) Expanding the scope of institutional analysis. In: Powell WW, DiMaggio PJ (eds) The new institutionalism in organizational analysis. The University of Chicago Press, Chicago, pp 183-204

Rappaport A (1998) Creating shareholder value, 2nd edn. Free Press, New York

Roberts RW (1992) Determinants of corporate social responsibility disclosure: an application of stakeholder theory. Acc Organ Soc 17:595-612

Shannon CE, Weaver W (1998) The mathematical theory of communication. University of Illinois Press, Urbana

Siegel DS, Vitaliano DF (2007) An empirical analysis of the strategic use of corporate social responsibility. J Econ Manag Strategy 16(3):773-792

Tate WL, Ellram LM, Kirchoff JF (2010) Corporate social responsibility reports: a thematic analysis related to supply chain management. J Supply Chain Manag 46(1):19-44

Thomson One Banker (2009) http://banker.thomsonib.com/. Accessed Dec 2009

Van der Laan-Smith J, Adhikari A, Tondkar RH (2005) Exploring differences in social disclosures internationally: a stakeholder perspective. J Account Public Policy 24(2):123-151

Verrecchia RE (1983) Discretionary disclosure. J Account Econ 5:179-194 
Watts RL, Zimmermann JL (1978) Towards a positive theory of the determination of accounting standards. Account Rev 53(1):112-134

Watts RL, Zimmermann JL (1986) Positive accounting theory. Prentice hall, London

Watts RL, Zimmermann JL (1990) Positive accounting theory: a ten year perspective. Account Rev 65(1):131-156

Whitley R (1999) Divergent capitalisms: the social structuring and change of business systems. Oxford University Press, Oxford 